\title{
References
}

Geay Y., Robelin J., Beranger C., Micol D., Gueguen L., Malterre C., 1978. Bovins en croissance et à l'engrais. In : "INRA, Alimentation des Ruminants". INRA Publications Versailles, 297-344.

Jarrige R., Journet M., Verite R., 1978. Azote. In : "INRA, Alimentation des Ruminants". INRA Publications Versailles, 89-128.

Robelin J., Geny Y., 1978. Estimation de la composition chimique du corps entier des bovins à partir du poids des dépôts adipeux totaux. Ann. Zootech. 27, 159-167.

Verite R., Journet M., JaRrige R., 1979. A new system for the protein feeding of ruminants : the PDI system. Liv. Prod. Sci., 6, 349-367.

Vermorel M., 1978a. Energie. In : "INRA, Alimentation des Ruminants". INRA Publications Versailles, 48-88.

Vermorel M., 1978b. Feed evaluation for ruminants. II. The new energy systems proposed in France. Liv. Prod. Sci., 5, 347-366.

\section{Federal Republic of Germany energy and protein feeding standards for growing and fattening cattle}

\author{
R. DAENICKE \\ Institut für Tierernährung, \\ 3300 Braunschweig - FAL, Bundesallee 50, (Federal Republic of Germany).
}

Beef' production in the Federal Republic of Germany is based mainly on fattening of bulls. Steers being negligible, only a small number are fattened on pasture. Heifers and cows are not normally fed special fattening rations. Most of these animals are slaughtered because of low yield, sterility or disease.

Male calves to be fattened are bred almost entirely in dairy herds i.e. they result from dual-purpose breeds. Although experiments have shown remarkable differences between bulls of these breeds with respect to protein and fat deposition, there are no specific recommendations for practical use. In 1973 a working group of' the "Deutsche Landwirtschafts-Gesellschaft" calculated protein and energy feeding standards to be used for all fattening bulls in the Federal Republic of Germany (Table 1).

The experimental background of these standards was :

1. Measurements of protein and fat deposition of Friesian bulls by whole body analysis (liveweight range $150-600 \mathrm{~kg}$ ).

2. Feeding experiments with growing bulls.

3. Records of practical farms.

Rations were based on concentrates and maize silage or beet top silage supplemented by some hay. In some cases sheep were used to measure the digestibility of the feedstuffs.

As shown in Table 1 recommendations for net energy are given for different daily gains. The omission of figures for the extreme rates of daily gain in parts of the Table is to indicate that these extremely low or high rates of gain do not have practical relevance at the respective intervals in the fattening period.

Protein feeding standards are about $10-20$ per cent higher than the real requirements. This is to avoid negative effects on performance if crude protein content in forage is overestimated. 
TABLE 1

DAILY NUTRIENT REQUIREMENT OF DUAL PURPOSE BULLS (DEUTSCHE LANDWIRTSCHAFTSGESELLSCHAFT, 1973)

\begin{tabular}{|c|c|c|c|c|c|c|c|c|c|}
\hline \multirow{2}{*}{$\begin{array}{c}\text { Liveweight } \\
\text { kg }\end{array}$} & \multirow{2}{*}{$\begin{array}{c}\text { Digestible } \\
\text { crude } \\
\text { protein } \\
g\end{array}$} & \multicolumn{8}{|c|}{ Net energy (SE $)^{1}$} \\
\hline & & & Do g & 1 & $000 \mathrm{~g}$ & 1 & $200 \mathrm{~g}$ & 1 & $400 \mathrm{~g}$ \\
\hline 150 & 500 & & 200 & & 2400 & & - & & - \\
\hline 200 & 550 & 2 & 550 & & 2800 & 3 & 100 & & - \\
\hline 250 & 600 & & - & & 3200 & 3 & 550 & 3 & 950 \\
\hline 300 & 650 & & - & & 3600 & 4 & 000 & 4 & 500 \\
\hline 350 & 700 & & - & & 4000 & 4 & 400 & 4 & 900 \\
\hline 400 & 750 & & - & & 4300 & 4 & 750 & 5 & 250 \\
\hline 450 & 800 & 4 & 250 & & 4600 & 5 & 100 & 5 & 700 \\
\hline 500 & 800 & 4 & 600 & & 5000 & 5 & 550 & & - \\
\hline 550 & 800 & 4 & 950 & & 5400 & 6 & OOO & & - \\
\hline 600 & 800 & 5 & 300 & & 5800 & & - & & - \\
\hline
\end{tabular}

$1 \mathrm{SE}=$ Starch Equivalent $=9.9 \mathrm{MJ}$

There are no special energy and protein feeding standards for the fattening of heifers in the Federal Republic of Germany. The only data available are for the rearing of heifers, and these are given in Table 2 . These recommendations are based mainly on data from practical feeding experiments and records of the extension services.

TABLE 2

DAILY NUTRIENT REQUIREMENTS FOR REARING OF HEIFERS (DEUTSCHE JAANDWIRTSCHAFTSGESELLSCHAFT, 1978)

\begin{tabular}{|c|c|c|c|}
\hline Liveweight & $\begin{array}{l}\text { Digestible } \\
\text { crude protein }\end{array}$ & Net_es & $\underline{Y}-(S E)$ \\
\hline \multirow[t]{2}{*}{$\mathrm{kg}$} & g & & \\
\hline & & $500 \mathrm{~g}$ & 700 \\
\hline
\end{tabular}

\begin{tabular}{|c|c|c|c|c|}
\hline 175 & 400 & & 800 & 2 \\
\hline 225 & 450 & 2 & 200 & $?$ \\
\hline 275 & 500 & 2 & 600 & \\
\hline 325 & 550 & 3 & $\mathrm{COO}$ & \\
\hline 375 & 600 & 3 & 400 & \\
\hline 425 & 600 & 3 & 800 & \\
\hline 175 & 600 & 4 & 200 & 5 \\
\hline
\end{tabular}

